\title{
Dark-Season Survival Strategies of Coastal Zone Zooplankton in the Canadian Arctic
}

\author{
ROBERT J. CONOVER ${ }^{1}$ and TIMOTHY D. SIFERD ${ }^{2}$
}

(Received 9 June 1992; accepted in revised form 10 November 1992)

\begin{abstract}
For herbivorous zooplankton, surviving the arctic winter requires that sufficient energy be stored in summer to enable ten months or more of possible starvation. Energy and materials for reproduction may also be totally derived from stored lipid and bodily protein. The predominant storage products are wax esters, often visible as translucent droplets or a fusiform inclusion in the tissues. Lipid may constitute more than $50 \%$ of dry weight at the end of summer. Reproduction is synchronized with season and environmental conditions to enable offspring to exploit the brief period of intense primary production. So far as we know, fertilization occurs only once in the copepods studied here, which make up more than $98 \%$ of the total zooplankton by numbers, and males are short lived, but in one species (Calanus hyperboreus) females may survive into a second productive season, thereby storing sufficient reserves to spawn a second time. Several planktonic species, including larval invertebrates, start growth early by utilizing algae that develop on the under-ice surface several months before the pelagic phytoplankton bloom. The minimum water temperature $\left(-1.8^{\circ} \mathrm{C}\right)$ is constant and much warmer than the atmosphere, so overwintering should be less stressful for aquatic species than for terrestrial forms. Additional adaptations used by zooplankton in winter include seeking deeper water to escape predation, reducing swimming costs by regulating buoyancy, and further lowering metabolic rates by limiting synthesis of enzymes and increasing the fraction of lipid used in respiration.
\end{abstract}

Key words: copepods, zooplankton, phytoplankton, ice-algae, fast ice, lipid, overwintering, survival strategies, growth, reproduction

RÉSUMÉ. Afin de survivre à l'hiver arctique, le zooplancton herbivore doit stocker suffisamment d'énergie en été pour faire face à 10 mois ou plus de famine potentielle. Il se peut aussi que l'énergie et les matériaux servant à la reproduction soient tirés en totalité des lipides emmagasinés et des protéines du tissu corporel. Les produits stockés les plus importants sont les esters cireux, souvent visibles sous la forme de gouttelettes translucides ou d'une inclusion fusiforme dans les tissus. Les lipides peuvent constituer plus de $50 \mathrm{p}$. cent du poids $\mathrm{sec}$ à la fin de l'été. La reproduction est synchronisée avec les saisons et les conditions environnementales de façon à permettre à la progéniture de profiter de la courte période de production primaire intense. Dans l'état de nos connaissances actuelles, la fertilisation a lieu une seule fois chez les copépodes qui nous intéressent, et qui constituent plus de $98 \mathrm{p}$. cent du zooplancton total sur le plan numérique. Les mâles ont une durée de vie relativement courte, mais dans l'espèce Calanus hyperboreus, les femelles peuvent vivre assez longtemps pour entrer dans une deuxième phase de reproduction, stockant ainsi suffisamment de réserves pour frayer une seconde fois. Plusieurs espèces planctoniques, y compris des invertébrés larvaires, commencent à croître de bonne heure, en utilisant les algues qui se développent sur le dessous de la glace plusieurs mois avant la prolifération du phytoplancton pélagique. La température minimale de $1^{\prime}$ eau $\left(-1,8^{\circ} \mathrm{C}\right)$ est constante et beaucoup plus élevée que l'atmosphère, ce qui devrait rendre la survie hiémale moins stressante pour les espèces aquatiques que pour les formes terrestres. Parmi les autres adaptations utilisées par le zooplancton en hiver, on compte la recherche d'eaux plus profondes pour échapper aux prédateurs, la réduction du coût de la natation grâce à une régulation de la flottabilité, ainsi que la réduction du taux de métabolisme par une limite de la synthèse des enzymes et l'augmentation de la portion de lipides utilisés dans la respiration.

Mots clés : copépodes, zooplancton, phytoplancton, algues glaciaires, banquise côtière, lipides, survie hiémale, stratégies de survie, croissance, reproduction

Traduit pour le journal par Nésida Loyer.

\section{INTRODUCTION}

How arctic zooplankton survive the dark period when primary production is totally light limited is poorly understood, in part because year-round investigations of the pelagic community at high latitudes, where ice is a major environmental influence, are rare (Ussing, 1938; Grainger, 1959; Bursa, 1961). Detailed information on life cycles from the central basin of the Arctic Ocean is available for only one zooplankton species, Calanus hyperboreus, from two manned ice islands (T-3, Dawson, 1978; "North Pole," Rudyakov, 1983), and information on seasonal changes in dry weight and lipid content is known only for the same species, also from T-3 (Lee, 1974). Hence, much of our information on arctic zooplankton during winter is by extrapolation from sites somewhat south of the Arctic Circle ( $\emptyset$ stvedt, 1955; Maclellan, 1967) or from high latitude areas where climate and currents have partially ameliorated "typical" polar conditions (Hopkins, 1981; Tande et al., 1985).
A similar situation prevails in the Southern Hemisphere despite years of investigation of krill. The distribution of the dominant species of zooplankton is reasonably well known, but much of the research on physiology and biochemistry has been concentrated in the austral summer (Conover and Huntley, 1991). Food may not always be limiting in winter there, because most of the ocean south of the Polar Front (about $50^{\circ} \mathrm{S}$ ) is still north of the Antarctic Circle and, therefore, does not experience polar night. Euphausia superba Dana may live 5-8 years, can spawn at least three times during its lifetime, and has been observed to feed under pack-ice in winter (Smith and Schnack-Schiel, 1990). It also uses triglycerols as its primary storage lipid (Hagen, 1988), which implies a more or less continuous food supply (Sargent $e t$ al., 1981). Indeed, euphausiids are found only in marginal seas in the high North, which may be because they cannot regulate their metabolism and reduce food requirements despite prolonged darkness (Kils, 1981; Clarke and Morris, 1983).

\footnotetext{
${ }^{1}$ Department of Fisheries and Oceans, Biological Sciences Branch, Bedford Institute of Oceanography, P.O. Box 1006, Dartmouth, Nova Scotia, Canada B2Y 4A2

2Department of Fisheries and Oceans, Central and Arctic Region, Freshwater Institute, 501 University Crescent, Winnipeg,

Manitoba, Canada R3T 2N6

CThe Arctic Institute of North America
} 
In any event, we propose to limit further discussion of the overwintering process to the arctic coastal zone, where conditions may be more severe and where copepods constitute more than $98 \%$ of total zooplankton by numbers.

\section{PHYSICAL CONDITIONS AND THEIR BIOLOGICAL IMPLICATIONS}

Temperature and light would seem to be the most important physical variables influencing the distribution of polar plankton. Of the two, temperature would not directly limit survival while light, if insufficient to permit primary production, could. However, cold temperature also leads to ice formation, which in turn reduces light penetration and provides a surface for snow accumulation. Snow has a much greater capacity for absorption and reflection of incoming radiation than ice alone (Welch, 1991). Even so, the process of ice accumulation is partially self-damping because of the insulating properties of frozen water and, particularly, snow.

Ice formation has a number of additional implications potentially affecting the organisms living in its proximity. In salt water, the temperature of the density maximum decreases with increasing salinity to the freezing point, about $-1.8^{\circ} \mathrm{C}$. The resulting convection can generate a mixed layer of up to $40 \mathrm{~m}$ depth with a temperature near freezing. Continued cooling results in the formation of frazil ice within the water column, which floats to the surface, scavenging particles, including living plant cells, encountered during ascent (Garrison et al., 1990). Near the surface, crystals coalesce to form solid congelation ice, but the frazil ice may accumulate, with its organic contents, in layers up to $2 \mathrm{~m}$ thick, if not swept away by currents. It may be this enriched frazil ice layer that supports overwintering krill under Southern Ocean pack (Stretch $e t$ al., 1988).

Ice formation and melting have other properties potentially affecting the well-being and distribution of pelagic and ice-inhabiting organisms. The discontinuity between the icegenerated mixed layer and the waters beneath may be a seasonal barrier to zooplankton migration. Then, during freeze-up, the salt in sea water is largely extruded from the ice, leaving nutrient-rich brine pockets behind. Developing ice-algal blooms initially depend on this entrapped nutrient, but later strong nutrient gradients develop in and just under the ice (Cota et al., 1987; Harrison et al., 1990; Smith et al., 1990). Also, brine formation during freeze-up and reduced salinities during melt place animals living on or near the ice under osmotic stress. Thus sympagic (i.e., ice-associated) amphipods are euryhaline osmoregulators, while pelagic hyperiid amphipods cannot regulate their haemolymph concentration (Aarset and Aunaas, 1987).

The direct effects of low temperature on aquatic organisms may actually be beneficial. Sub-ice temperatures are nearly constant $\left(-1.8^{\circ} \mathrm{C}\right)$, keeping food requirements low during overwintering, but the real limit to under-ice existence is seasonality in food supply, which should have greater effect on the herbivores than on the omnivores and carnivores (Clarke, 1988). The primary thrust of this paper, then, is to examine overwintering success and adaptive mechanisms employed by the dominant members of the zooplankton community, all copepods, inhabiting the relatively shallow passages within the Canadian Arctic Archipelago.

\section{METHODS}

Most of the observations reviewed here were made near Resolute, Northwest Territories, in Resolute Passage/Barrow Strait in 1984, 1985, and 1986 (Fig. 1). Winter-spring observations were made through holes cut in fast ice at a station near the $100 \mathrm{~m}$ contour, and open-water collections were made from a semi-portable inboard-outboard launch in approximately the same depth of water near the site of the earlier ice station. Particulate matter and chlorophyll samples were taken with Niskin-type, messenger-operated water bottles, although near-ice samples were sometimes taken with a low-volume pump. Samples were filtered on glass-fiber paper and frozen immediately for later analysis. Zooplankton samples were taken with vertically hauled $0.5 \mathrm{~m}$ diameter nets $(100,200$, or $800 \mu \mathrm{m}$ mesh), sometimes equipped with a closing mechanism or with a pump near the under-ice surface, and either frozen for chemical analysis or preserved in $2 \%$ formalin for enumeration. Most samples of ice-algae were taken with a SIPRE corer, after first mechanically augering a hole through about $90 \%$ of the ice thickness. For details of the analytical methods, refer to Bedo et al. (1990).

\section{DESCRIPTION OF THE ENVIRONMENT AND SOME INHABITANTS}

Barrow Strait contains a sill that limits water flow through the Northwest Passage to $<125 \mathrm{~m}$, but it receives a mixture of several water types (Fig. 1). Arctic Ocean water passes through the archipelago in a generally easterly direction. That entering from the north is slightly more saline than that entering from the west or south. The warmest, saltiest water occurs below $100 \mathrm{~m}$, reflecting some mixing of arctic water with deeper Atlantic water (Prinsenberg and Bennett, 1987).

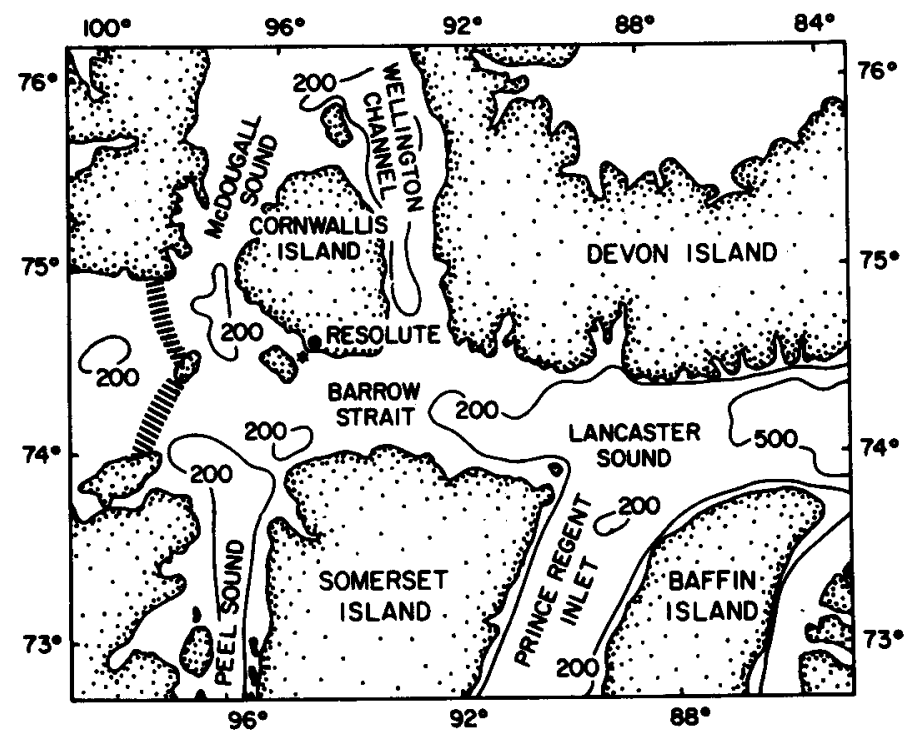

FIG. 1. Barrow Strait near Cornwallis Island, showing the approximate location of the sill (barred band) separating Viscount Melville Sound from Barrow Strait and Lancaster Sound. Station location $\left(74^{\circ} 38^{\prime}, 95^{\circ} 01^{\prime} \mathrm{W}\right)$ is shown by the star just southwest of Resolute. 
Polar night descends about 9 November and the sun does not reappear until early February. The sun does not set from 28 April until mid-August. Even during the light period, the average monthly irradiance received in the Resolute area as a percentage of that potentially available is generally less than $50 \%$ because of cloud, fog, and polar haze (Atmospheric Environment Service, 1984b, 1985b, 1986).

The fast-ice season usually extends from October into the following July (Fig. 2). Maximum ice thickness is around $2 \mathrm{~m}$ in May but varies from season to season, as does snow cover (compare Figs. 2A and B). Conductivity-temperaturedensity (CTD) measurements on the north side of Barrow Strait in late May-early June 1985 suggest that the depth of the mixed layer can be about 20-30 m (E.P.W. Horne, pers. comm. 1992). Tidal currents under the ice near Resolute can be greater than $25 \mathrm{~cm} \cdot \mathrm{s}^{-1}$ and are strongly elliptical, with maximum velocity and transport in an easterly direction (Prinsenberg and Bennett, 1989). In 1986, the fast-ice front lay just west of Resolute and our station, although on the fast ice, was considerably influenced by the proximity of open water. On several occasions during April and May, progressive-vector plots showed a breakdown of net easterly transport and a major change in water structure, including freshening of the surface water accompanied by increased chlorophyll and greater physiological activity in a certain zooplankton species (Bedo et al., 1990).

In this case the species was Pseudocalanus acuspes (Giesbrecht); other important species to be discussed here include Calanus hyperboreus (Krøyer), Calanus glacialis Jaschnov, and Metridia longa (Lubbock). Such calanoid copepods undergo exactly twelve molts between egg and adult, six naupliar stages (N1-N6), and following metamorphosis, six copepodid stages, $\mathrm{C} 1-\mathrm{C} 5$, plus $\mathrm{C} 6$, the adult
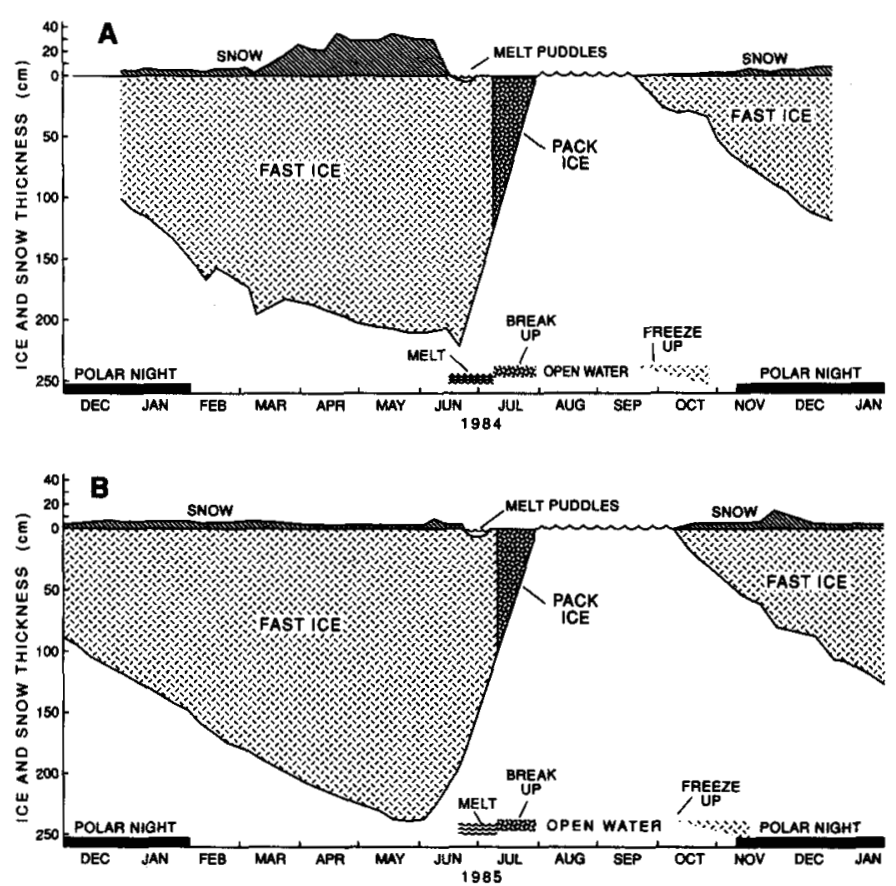

FIG. 2. Seasonal distribution of ice and snow thickness and approximate length of breakup and open water seasons at Resolute, N.W.T., for A 1984; B 1985 (Atmospheric Environment Service, 1984a, 1985a). male and female. This nomenclature is used later when discussing life-cycle characteristics.

\section{LIGHT SEASON CONDITIONS}

Phytoplankton populations at the beginning of April were very low in 1984 and had little increase before July (Fig. 3). Chlorophyll-breakdown products (phaeopigments), much in fecal pellets, are evidence for zooplankton grazing during April and May, when they constituted more than $50 \%$ of the total pigment. Only total pigment was determined during most of the open water season, but an enormous increase in potential food became available for the actively growing zooplankton at this time.

Despite low chlorophyll levels in the water column in early spring, some nutritional resources are present. Mention was made of ice-algal blooms in an earlier section. Near Resolute the doubling time of ice-algal cells is $4-8$ days, yielding a maximum chlorophyll concentration of $150-300 \mathrm{mg} \mathrm{Chl} \cdot \mathrm{m}^{-2}$ in mid-May (Welch and Bergmann, 1989), which is more than that in the remaining water column at the same season, and it is concentrated in a layer of ice only a few centimetres thick. Loose frazil ice, often associated with the drifting Southern Ocean pack, does not accumulate so readily at the bottom of arctic fast ice because of tidal currents, but attached cells proliferate and nurture a distinct sympagic community of micro- and macro-invertebrates (Cross, 1982; Kern and Carey, 1983; Carey, 1985; Grainger et al., 1985). Protozoans, worms, and small crustaceans, both larval and adult, live in the ice-algal layer, while amphipods of several genera eat ice-algae and probably other sympagic animals (Bradstreet and Cross, 1982; Carey and Boudrias, 1987; Lewis, 1987). Although hardly sympagic animals, several species of calanoid copepods, including Pseudocalanus spp. and Calanus glacialis, also feed on ice algae (Conover et al., 1986; Runge and Ingram, 1988).

In addition to the carbon and energy tied up in plants, there is a substantial amount of non-chlorophyll-containing carbon present in the water column (Fig. 4), some dead and possibly refractory, but also including living bacteria, protozoans, and small metazoans. Assuming a carbon:chlorophyll ratio of $\mathbf{5 0}$ for plants, there are perhaps 4-25 times more carbon in the non-plant pool during the early spring than in plants. While the proportion of plant carbon, as well as nitrogen and other

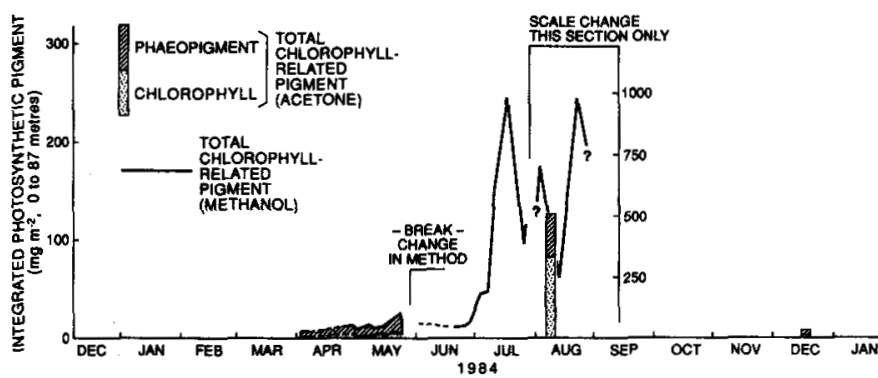

FIG. 3. Integrated photosynthetic pigments in $\mathbf{m g} \cdot \mathrm{M}^{-2}$ (total water column $0-87 \mathrm{M}$ ) over the spring through summer 1984 at our station in Barrow Strait. Spring measurements mainly made by BIO scientists (acetone method) and remainder made by scientists from the Freshwater Institute at Winnipeg (methanol method). 


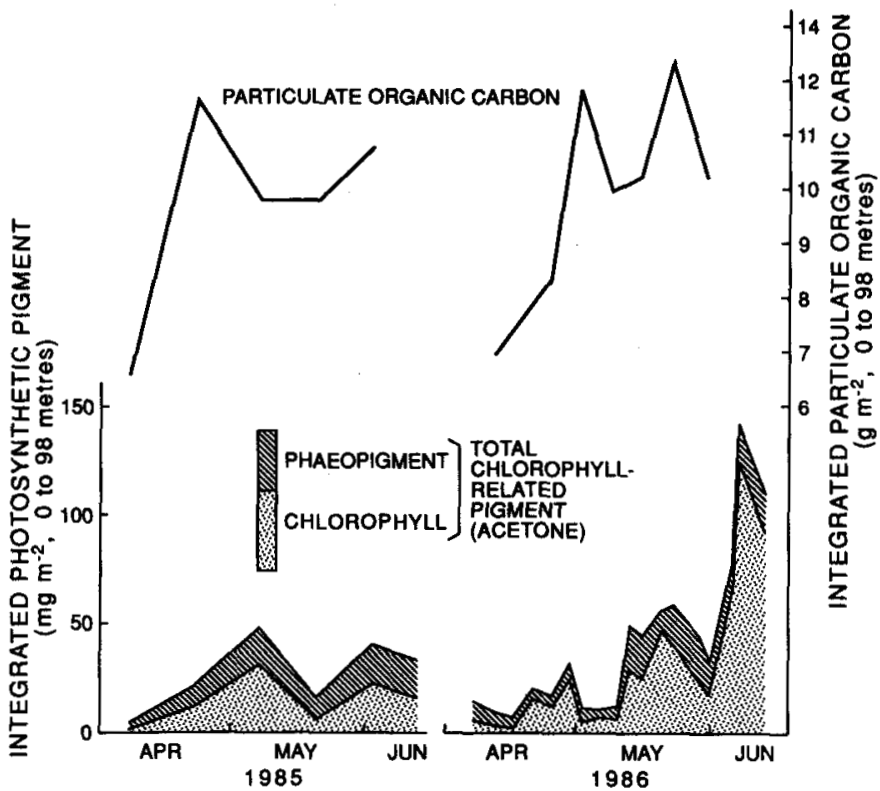

FIG. 4. Comparison of integrated particulate organic carbon in $\mathbf{g ~ C} \cdot \mathbf{M}^{-2}$ (total water column) with integrated photosynthetic pigment in $\mathrm{mg} \cdot \mathrm{M}^{-2}$ (total water column) for spring 1985 and 1986 at our station in Barrow Strait (Conover and Harris, unpubl.).

components of organic matter, increases substantially during the productive season and is largely responsible for animal growth, a rough extrapolation from Figure 4 back to midwinter would suggest a residual of perhaps $5-10{\mathrm{~g} \mathrm{C} \cdot \mathrm{m}^{-2}}^{-2}$ in the water column that might be utilized by some animals as a hedge against starvation.

Rates of sedimentation under fast ice can provide information on the proportion of sympagic production that is used in the water column and that reaches the bottom. During the ice-algal bloom of 1984, diatoms and fecal pellets were counted directly, their relative volume determined by image analysis and then converted to carbon following Emerson and Roff (1987). As shown by Anning (1989), sedimenting diatom-carbon increased by more than an order of magnitude from April through June, although the June peaks probably included a large fraction of previously accumulated sympagic cells lost from the now melting ice (Fig. 5A). The fecal-pellet carbon was quite large (Fig. 5B) and proportionately more important early in the bloom (Fig. 5C). The total flux would seem to be at least $10 \%$ of the standing crop, judging by 1985 and 1986 data at the same season (Fig. 4). There would appear to be a constant rain of potential nutriment to the benthos in the spring, despite relatively low primary production in the water column.

As mentioned above, a relatively large fraction of the sympagic production was converted to fecal pellets in 1984 (Figs. 3, 5B, 5C). We believe this was related to the substantially larger dry-weight biomass of zooplankton observed during April and May of that year, compared with that of 1985 and 1986 (Fig. 6), which was caused by swarms of ravenously hungry Pseudocalanus acuspes (Conover et al., 1986; Conover et al., 1991).

During the remainder of the light season, the total zooplankton biomass did not vary greatly over the three years
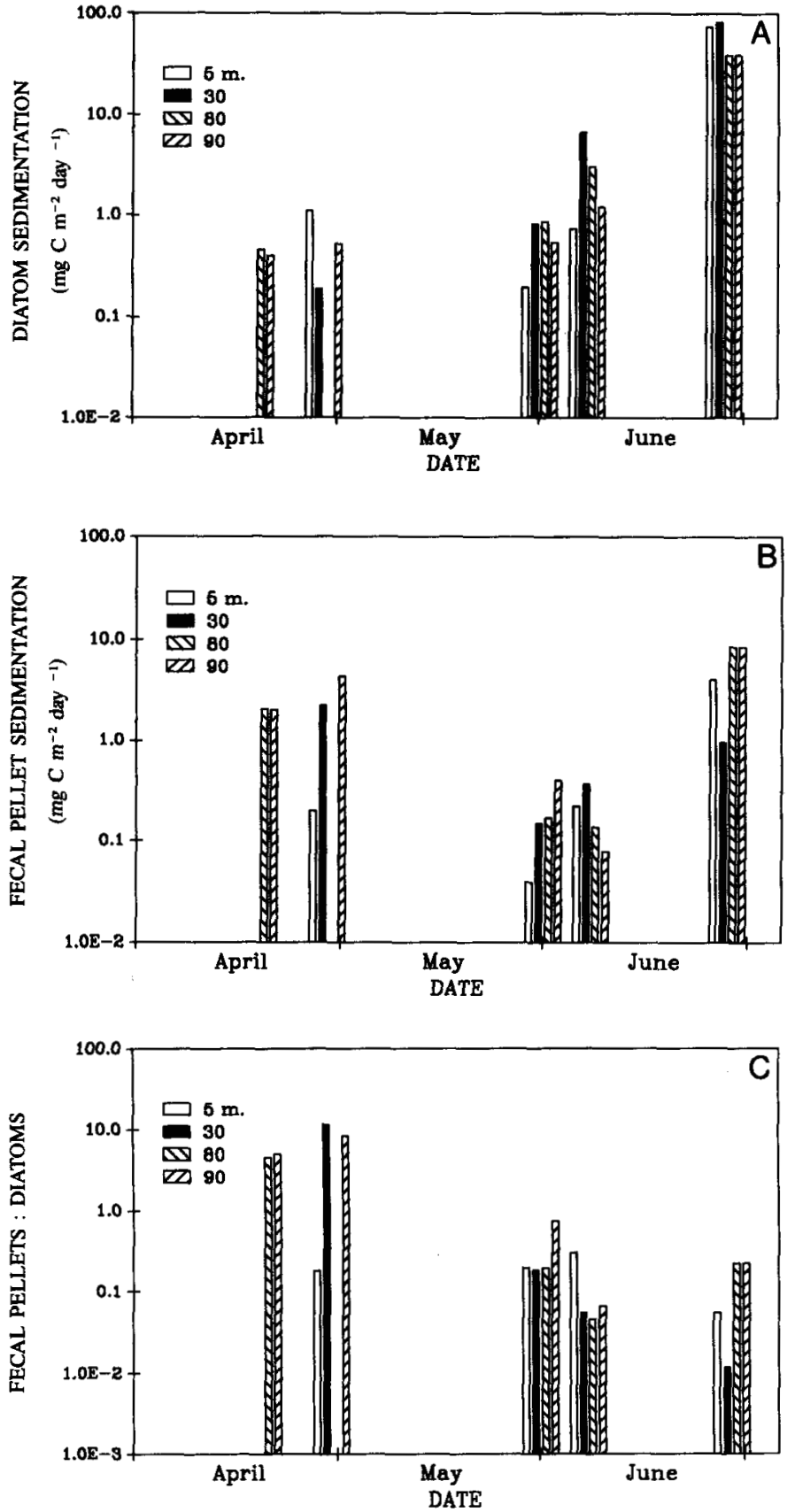

FIG. 5. Sedimentation of diatoms (A) in $\mathrm{mg} \mathrm{C} \cdot \mathrm{M}^{-2 \cdot \mathrm{d}^{-1}}$ at four depths, fecal pellets (B) in $\mathrm{mg} \mathrm{C} \cdot \mathrm{M}^{-2 \cdot} \cdot \mathrm{d}^{-1}$ at the same four depths; and the fecal pellet:diatom ratio (C) in the sediment collected at four depths over spring 1984 at our station in Barrow Strait (Anning, 1989).

illustrated (Fig. 6). However, mean dry weight of individual developmental stages of Pseudocalanus acuspes increased substantially in summer of 1986 following breakup and onset of the phytoplankton bloom, after decreases during the spring when the food resources were probably limiting (Fig. 7). Population numbers also decreased during spring 1986, but in other years there was little change.

The two Calanus species showed a somewhat similar growth response by individuals of a given stage, but none showed a clear increase in population abundance until midsummer. Weight increases for individual stages are largely 


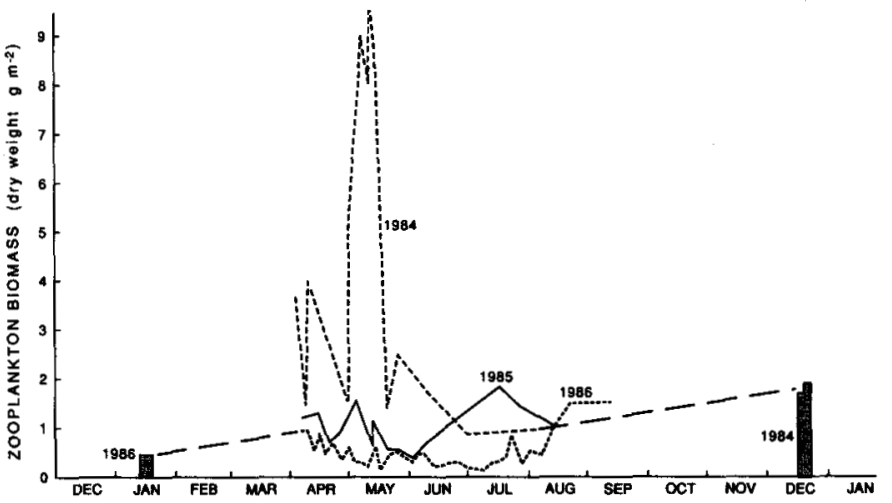

FIG. 6. Mean dry weight biomass of zooplankton in $\mathrm{g} \cdot \mathrm{M}^{-2}$ at our station in Barrow Strait integrated over the total water column for three years 1984, 1985, and 1986 (Conover and Harris, unpubl.).

TABLE 1. Chlorophyll-related pigment distribution in the upper $30 \mathrm{~m}$ before, during, and after the dark period 1984-85 and 1985-86 (Siferd and Harris, unpubl.)

\begin{tabular}{lcccc}
\hline \hline Date & $\begin{array}{c}\text { Chlorophyll } \\
\left(\mathrm{mg}^{\prime} \mathrm{m}^{-2}\right)\end{array}$ & $\begin{array}{c}\text { Phaeopigment } \\
\left(\mathrm{mg}^{-2}\right)\end{array}$ & $\begin{array}{c}\text { Total } \\
\left(\mathrm{mg}^{-2} \mathrm{~m}^{-2}\right)\end{array}$ & $\begin{array}{c}\text { Chlorophyll: } \\
\text { phaeopigment } \\
\text { ratio }\end{array}$ \\
\hline $08 / 08 / 84$ & 142.78 & 37.27 & 180.05 & 3.83 \\
$12 / 18 / 84$ & 0.58 & 2.11 & 2.69 & 0.27 \\
$04 / 07 / 85$ & 1.27 & 1.03 & 2.30 & 1.23 \\
$06 / 12 / 85$ & & & & \\
(pre-bloom) & 11.02 & 7.14 & 18.16 & 1.54 \\
$01 / 15 / 86$ & 0.63 & 0.99 & 1.62 & 0.64 \\
$04 / 07 / 86$ & 3.04 & 2.15 & 5.19 & 1.41 \\
\hline
\end{tabular}

related to lipid storage, lipid generally being greater than $50 \%$ of dry weight (Harris and Conover, unpubl.).

\section{THE DARK SEASON}

Only two stations have been occupied during mid-winter, 18-19 December 1984 and 15 January 1986, summarized by histograms in Figures 3 and 6, and they are unique for the Canadian High Arctic. Admittedly they represent a limited data set from which to deduce what the zooplankton might be doing in the dark period, but we shall try to do so.

Chlorophyll and related pigments were measured in midwinter, but not carbon. Pigment information for 18-19 December 1984 and 15 January 1986 is bracketed by the comparable information for the nearest stations in time (Table 1). The August 1984 observations were nearly two orders of magnitude larger than those for December 1984

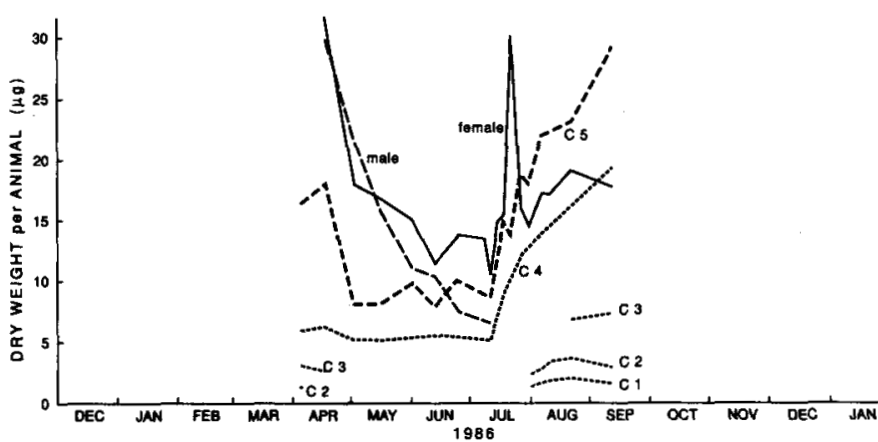

FIG. 7. Seasonal change in mean dry weight $\left(\mu \mathrm{g}\right.$ animal $\left.{ }^{-1}\right)$ of individual stages of Pseudocalanus acuspes at our station in Barrow Strait (Harris, unpubl.).

and had a relatively large chlorophyll:phaeopigment (Chl:Ph) ratio. The 7 April 1985 pigment estimate was similar to that for the previous December, but the low Chl:Ph ratio during the dark period suggested that few living plant cells were present; by early April the greater $\mathrm{Chl}: \mathrm{Ph}$ ratio indicated some primary production. There were no pigment data for late summer 1985, and the 12 June data preceded breakup. However, the January 1986 data show a low standing stock of total pigment and more phaeopigment than chlorophyll, as in the previous winter. The spring sample (7 April 1986) shows more signs of biological activity than in 1985, which could be related to the proximity of open water near the fastice station.

A similar comparison was made for the zooplankton (Table 2). Looking first at the 1984-85 data, the increase in biomass from August to December makes sense because there was certainly a large residual of chlorophyll and carbon from the summer blooms to foster growth in the individual copepods (Table 1). Continued reproduction might also be expected in fall for all species except the winter-breeding Calanus hyperboreus, which is confirmed by increased numbers in the other three species. During the dark period of 1984-85, total biomass decreased and total numbers and biomass for individual species decreased in every case except that individual Pseudocalanus would seem to have become larger, perhaps due to differential mortality. In 1985-86, the number and biomass of most species increased over the dark period (Table 2), which may be related to increased food supply because of the open water or greater advective transport near the fast-ice front (Bedo et al., 1990).

The distribution of developmental stages of the four species in the dark period and at the beginning of the light season

TABLE 2. Zooplankton numbers and dry weight biomass for dominant species for the total water column before, during, and after the dark period 1984-85 and 1985-86 (Conover, Siferd, and Harris, unpubl.)

\begin{tabular}{|c|c|c|c|c|c|c|c|c|c|c|}
\hline \multirow[b]{2}{*}{ Date } & \multirow{2}{*}{$\begin{array}{c}\text { No. total } \\
\cdot \mathrm{m}^{-2}\end{array}$} & \multirow{2}{*}{$\begin{array}{c}\text { Biomass } \\
\text { total } \\
\left(\mathrm{g} \cdot \mathrm{m}^{-2}\right)\end{array}$} & \multicolumn{2}{|c|}{ Pseudocalanus acuspes } & \multicolumn{2}{|c|}{ Calanus hyperboreus } & \multicolumn{2}{|c|}{ Calanus glacialis } & \multicolumn{2}{|c|}{ Metridia longa } \\
\hline & & & No:m ${ }^{-2}$ & $\mathrm{~g} \cdot \mathrm{m}^{-2}$ & No $m^{-2}$ & $g \cdot m^{-2}$ & No.m-2 & $\mathrm{g} \cdot \mathrm{m}^{-2}$ & No:m-2 & $\mathrm{g} \cdot \mathrm{m}^{-2}$ \\
\hline $08 / 05 / 84$ & 89400 & 0.970 & 42260 & 0.132 & 9537 & 0.706 & 321 & 0.130 & 15 & 0.002 \\
\hline $12 / 18 / 84$ & 176850 & 1.710 & 163200 & 0.562 & 1543 & 0.895 & 1324 & 0.185 & 896 & 0.068 \\
\hline $04 / 05 / 85$ & 102900 & 1.221 & 99000 & 0.782 & 280 & 0.304 & 468 & 0.100 & 255 & 0.035 \\
\hline $08 / 14 / 85$ & 71850 & 1.053 & 48150 & 0.099 & 4151 & 0.857 & 1294 & 0.082 & 51 & 0.015 \\
\hline $01 / 15 / 86$ & 16800 & 0.457 & 8140 & 0.062 & 529 & 0.276 & 499 & 0.079 & 596 & 0.040 \\
\hline $04 / 04 / 86$ & 53050 & 0.978 & 46650 & 0.554 & 616 & 0.214 & 1390 & 0.149 & 1099 & 0.061 \\
\hline
\end{tabular}


(Fig. 8) appears to be more or less compatible with the interpretation for 1984 from Table 2. For Pseudocalanus and Calanus hyperboreus the presumably more vulnerable younger stages have disappeared, but the distribution of later stages has not changed appreciably. Younger stages of Metridia longa and Calanus glacialis also disappeared, but an increase in the proportion of later stages in each species suggests that some individuals have grown over winter. For $M$. longa, generally recognized to be an omnivore, this is not really surprising if there was animal food available, but for C. glacialis omnivory is not so widely recognized.

Behavior of the four species between January and April 1986 was not so clear (Fig. 8). The Metridia longa population seemed to be more advanced in January than in December 1984, but the population structure in April was similar to the previous year. Calanus glacialis populations were also more advanced in 1986, but the only evidence for growth was a proportional increase in stage $\mathrm{C} 4$ over $\mathrm{C} 3$ between January and April. As all four species showed evidence for some "growth" in numbers or weight or both (Table 2), the winter and spring populations of zooplankton, like the pigment (Table 1), do not appear entirely comparable between years.

Reproduction in Calanus hyperboreus was initiated under the ice in the dark in the High Arctic. In both years, a few males were found for the first time since the previous spring in December or January (Fig. 8) and females showed evidence for gonad maturation. By mid-January some females were fully mature. Females with ripe gonads have been observed regularly off Resolute from mid-March through May. This and additional data have been used to describe the generalized life cycle of this species (Conover, 1988).

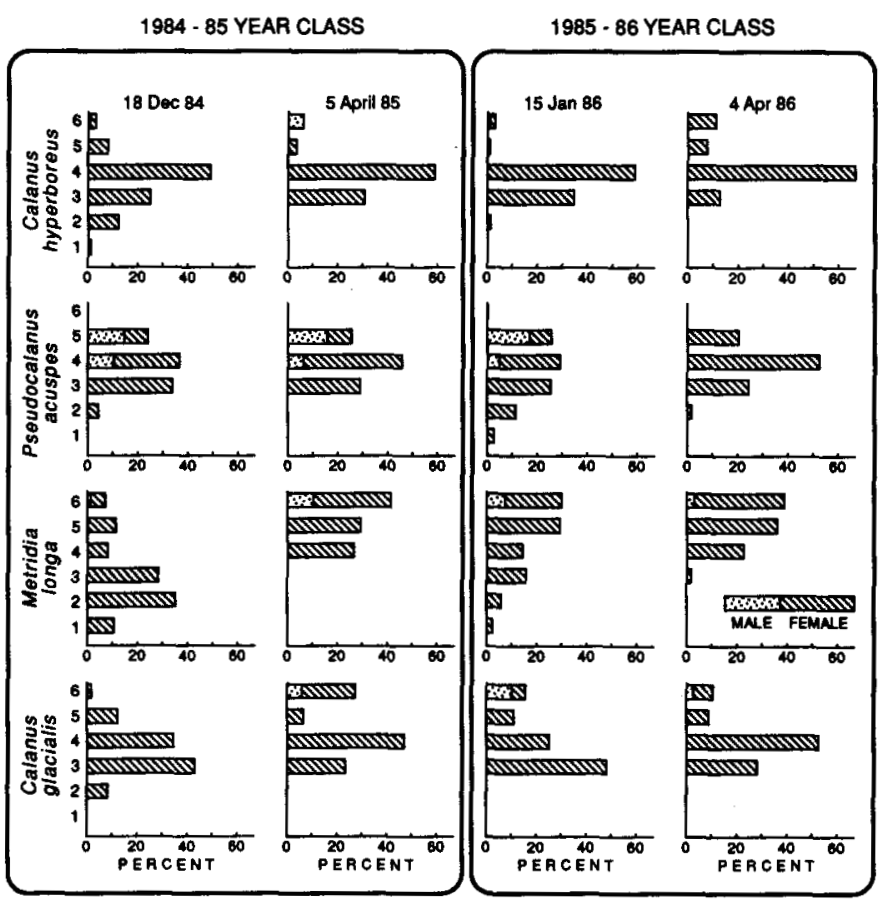

FIG. 8. Change in population structure, as percentage of total numbers for the species, for the four dominant species at our station in Barrow Strait over two successive dark periods, 18 December 1984 to 5 April 1985 and 15 January 1986 to 4 April 1986 (Conover, Harris, and Siferd, unpubl.).
In a series of new experiments in 1989 , the spawning behavior and weight loss, calculated from bodily dimensions and that of the oil sac, of 23 female $C$. hyperboreus was followed from 18-23 March until 16 August, maintaining the animals at environmental temperature in unfiltered water without supplementary rations (Conover and Harris, unpubl.). Most of the animals survived into the post-breakup period and about half showed growth in lipid stores once the summer phytoplankton bloom became established (Fig. 9). This animal produced over 1500 eggs in about ten weeks without feeding. Over this period its calculated "dry weight" decreased by $84 \%, 42 \%$ of which was converted to reproductive products. During the recovery period of four weeks, its daily growth rate was about $2.2 \%$ and it more than doubled its final starvation weight. The implication is that $C$. hyperboreus can be iteroparous, i.e., capable of spawning in two successive reproductive seasons, which would seem a useful survival strategy for a species with a prolonged life cycle inhabiting an environment with a seasonally limited food supply.

\section{DISCUSSION AND CONCLUSIONS}

Although the data for certain seasons are very limited or absent, several points can be made about the distribution of the copepod zooplankton in the Northwest Passage. First, with the exception of 1984, when Pseudocalanus was overwhelmingly abundant under the ice in spring, there is no clear

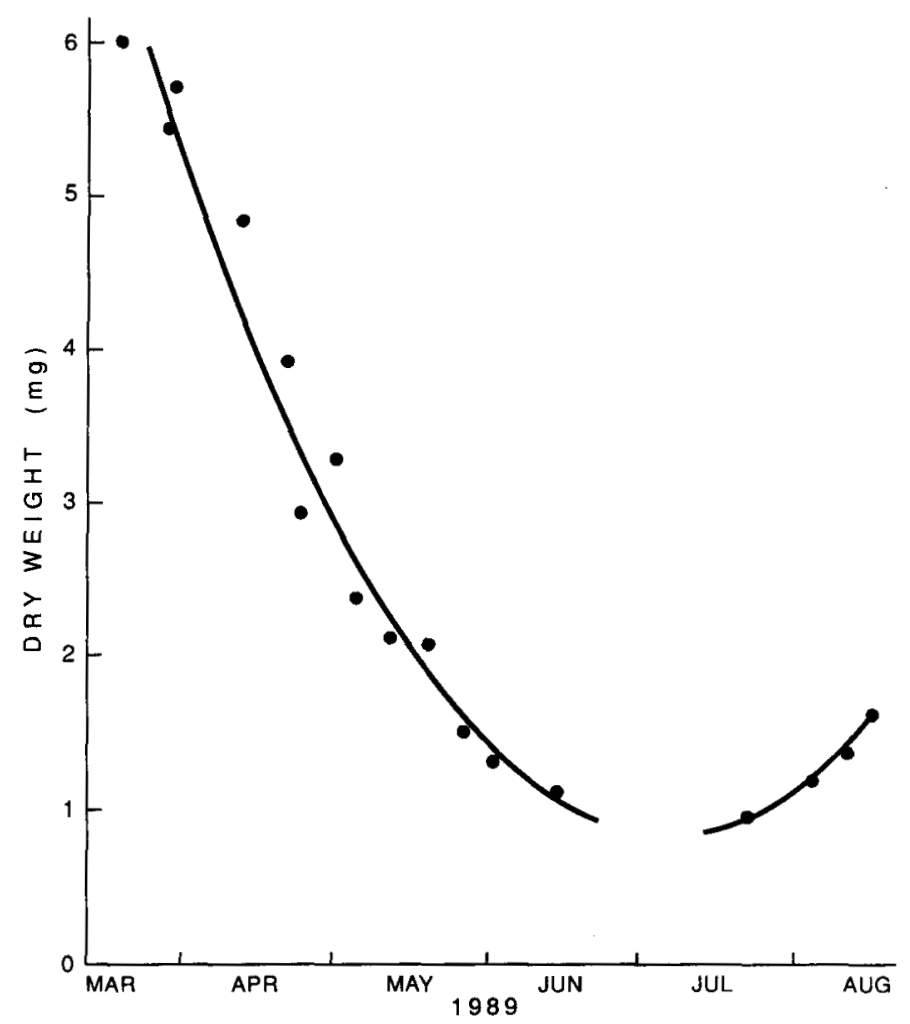

FIG. 9. Calculated loss in dry weight (mg-animal ${ }^{-1}$ ) over the winter-spring spawning period for a representative female Calanus hyperboreus, with calculated weight gain for the same female once the pelagic bloom became established in Barrow Strait. Data fitted to an exponential model using SYSTAT (Conover, unpubl). 
seasonal trend in total dry weight biomass for the four dominant copepods (Fig. 6), suggesting that food for the next trophic level in the arctic food web is nearly always available. Second, the same four species have somewhat different life cycles, but each achieves a similar biomass year after year. This consistent performance is related to maximal use of the brief phytoplankton bloom primarily for energy storage, especially in the later developmental stages, while using other nutritional sources, such as ice-algae, microbial- and other heterotrophically generated carbon, and detritus, for structural growth and perhaps for gonad maturation. Yet all but Calanus hyperboreus seem to require pelagic primary production to sustain reproduction.

To elaborate on the life cycle strategies, Pseudocalanus acuspes, the smallest species, can complete a generation in one year by overwintering mainly as developmental stages C3-C5, completing maturation using sympagic production. Spawning of newly fertilized females begins in late spring and continues most of the summer, but its development rate is sufficiently rapid that both structural growth and enough lipid storage take place to permit overwintering of a range of developmental stages (Fig. 8).

In Calanus hyperboreus, $\mathrm{C} 4$ is the dominant overwintering stage and there does not appear to be much change in population structure during the dark period (Fig. 8). However, there is continuous molting at a low rate from C5 to mature males and females all winter. Reproduction takes place in deep water using primarily lipid (wax ester) stored during the previous ice-free season, together with the female's bodily protein, and newly laid buoyant eggs float to the underice surface as they develop so that naupliar stages (N4-N6) are proximal to the sympagic algae on which they feed (M.D.G. Lopez, pers. comm. 1988). Most young have reached $\mathrm{C} 1$ by breakup. From this stage, there is still considerable confusion about the most common pattern of development. Although $\mathrm{C} 3$ and $\mathrm{C} 4$ do not seem to store much lipid (Fig. 10), both can overwinter (Fig. 8), but it is not clear when $\mathrm{C} 3$ molt. It seems doubtful that $\mathrm{C} 4$ can be achieved in one growth season. Some $\mathrm{C} 4$ probably molt early in spring to $\mathrm{C} 5$ and others somewhat later, but $\mathrm{C} 5$ generally store considerable lipid in the open-water season (Fig. 10). These C5 mostly overwinter and produce short-lived, non-feeding males and smaller females, which reproduce after their third growth season. More difficult to explain are the large females found at the end of the summer bloom (Fig. 10). They could be females that molted too late in the spring to reproduce and so fattened all summer, perhaps spawning for the first time in mid-winter after their fourth growth season, or conceivably they could be iteroparous individuals preparing to spawn for the second time.

Calanus glacialis probably take two years to mature and reproduce here, as in the Barents Sea (Tande et al., 1985). In Hudson Bay, females underwent vertical migration during the ice-algal blooms and showed increased gut pigment when near the ice (Runge and Ingram, 1988), but such behavior was not observed near Resolute. Instead, active feeding and spawning were initiated in late May, when the sympagic algal population had begun to come off the ice (Harris, 1992). While $C$. glacialis nauplii became quite abundant in May

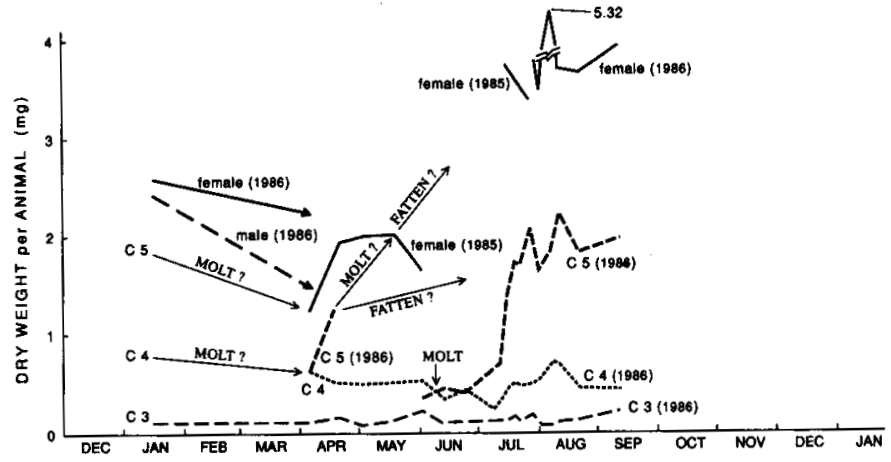

FIG. 10. Seasonal changes in dry weight (mg*animal ${ }^{-1}$ ) for individual stages of Calanus hyperboreus in Barrow Strait using data from 1985 and 1986 (Conover and Harris, unpubl.).

and June, younger copepodids (C1-C4) did not make a significant contribution to the population until August. These individuals may have contributed to a mid-winter peak of C3 (Fig. 8). Some further development may take place over the dark period, but fattening of late stages probably precedes a second overwintering and spawning at the start of their third season.

The life cycle of Metridia longa is understood least well of the several dominants at Resolute. While females show little gonad development until May or June, they are common in the population at any season (Fig. 8). Moreover, there is clear evidence for growth and development during the winter. Perhaps a portion of the population can complete a generation in one year. In laboratory experiments, late-stage Metridia and also Calanus glacialis readily ingested the large, wax-ester-containing eggs of $C$. hyperboreus, which are abundant in the water column during late winter and spring (Conover, unpubl.). These would constitute an easily caught, highly nutritious energy source to facilitate dark-season growth in any opportunistic species (Fig. 8).

We have emphasized lipid storage for later use as an energy and materials pool during starvation as an important survival strategy for zooplankton at high latitudes. As a second and perhaps equally important strategy, many zooplankton species have adopted some form of resting stage. At lower latitudes, a number of coastal species produce "diapause" eggs, which can survive long periods of harsh environmental conditions, usually in the bottom mud (Grice and Marcus, 1981; Marcus, 1990), but such adaptations are not known for polar zooplankton. Diapause was defined by Andrewartha (1952:99) as "as a stage in the development of certain animals during which morphological growth and development is suspended or greatly retarded." The term has been applied to freshwater cyclopoid copepods that remain inactive, with or without encystment, in the sediment over winter or during other unsuitable periods (Elgmork, 1955) and to marine calanoids by Carlisle and Pitman (1961), who obtained some evidence for hormonal control of metabolism in Calanus finmarchicus and Euchaeta norvegica. Evidence for some form of seasonally induced "resting" stage has been obtained for the arctic species Calanus hyperboreus (Conover and Corner, 1968; Head and Conover, 1983; Head and Harris, 1985) and C. glacialis (Arashkevich and Kosobokova, 1988), 
such as seeking deep water, regulating buoyancy, reducing activity and metabolism, changing the metabolic substrate oxidized during respiration, and lowering levels of digestive enzymes and gut peristalsis.

On the basis of these limited observations of polar zooplankton communities in the dark season, there is nonetheless considerable evidence of biological activity in winter, much of which we do not fully understand. Clearly year-round studies of polar plankton communities using contemporary methods are in order.

\section{ACKNOWLEDGEMENTS}

Many people have participated in our arctic field programs over the recent past and we thank them all. Special thanks go to colleagues Les Harris, Jeff Anning, Jeff Spry, and Kent Gustavson and to members of Harold (Buster) Welch's group from Fisheries and Oceans, Freshwater Institute, Central and Arctic Region, in Winnipeg, who have cooperated with us in the field and generously filled gaps in our data. Among numerous visitors we are especially grateful to Alan Bedo and Mai Lopez, who contributed ideas and unpublished information to this effort. Finally, this work could not have been accomplished without the logistical support and technical assistance of the Polar Continental Shelf Project (Energy Mines and Resources Canada), who have maintained facilities at Resolute, N.W.T., for the benefit of several generations of arctic researchers.

\section{REFERENCES}

AARSET, A.V., and AUNAAS, T. 1987. Osmotic responses to hyposmotic stress in the amphipods Gammarus wilkitzkii, Onisimus glacialis and Parathemisto libellula from arctic waters. Polar Biology 7:189-193.

ANDREWARTHA, H.G. 1952. Diapause in relation to the ecology of insects. Biological Reviews 27:50-107.

ANNING, J.L. 1989. The development and decline of the epontic algal community in Barrow Strait, N.W.T. M.Sc. thesis, University of Guelph. $86 \mathrm{p}$.

ARASHKEVICH, Ye.G., and KOSOBOKOVA, K.N. 1988. Life strategy of plant-eating copepods: Physiology and biochemistry of overwintering Calanus glacialis under starvation conditions. Oceanology 28:513-517.

ATMOSPHERIC ENVIRONMENT SERVICE. 1984a. Ice thickness data winter 1983-1984. Ottawa: Environment Canada, Ice Centre Climatology and Applications.

1985a. Ice thickness data winter 1984-1985. Ottawa: Environment Canada, Ice Centre Climatology and Applications.

$1984 \mathrm{~b}, 1985 \mathrm{~b}, 1986$. Monthly record meteorological observations in Canada. Ottawa: Environment Canada.

BEDO, A.W., HEAD, E.J.H., CONOVER, R.J., HORNE, E.P.W., and HARRIS, L.R. 1990. Physiological adaptations of an under-ice population of Pseudocalanus in Barrow Strait (N.W.T.) to increasing food supply in spring. Polar Biology 10:561-570.

BRADSTREET, M.S.W., and CROSS, W.E. 1982. Trophic relationships at High Arctic ice edges. Arctic 35(1):1-12.

BURSA, A.S. 1961. The annual oceanographic cycle at Igloolik in the Canadian Arctic. II. The phytoplankton. Journal of the Fisheries Research Board of Canada 18(4):563-615.

CAREY, A.G., Jr. 1985. Marine ice fauna: Arctic. In: Horner, R.A., ed. Sea ice biota. Boca Raton, Florida: CRC Press. 173-190.

CAREY, A.G., Jr., and BOUDRIAS, M.A. 1987. Feeding ecology of Pseudalibrotus (= Onisimus) litoralis Kröyer (Crustacea: Amphipoda) on the Beaufort Sea Inner Continental Shelf. Polar Biology 8:29-33.

CARLISLE, D.B., and PITMAN, W.J. 1961. Diapause, neurosecretion and hormones in Copepoda. Nature 190:827-828.

CLARKE, A. 1988. Seasonality in the Antarctic marine environment. Comparative Biochemistry and Physiology 90(B3):461-473.

CLARKE, A., and MORRIS, D.J. 1983. Towards an energy budget for krill: The physiology and biochemistry of Euphausia superba Dana. Polar Biology 2:69-86.

CONOVER, R.J. 1988. Comparative life histories in the genera Calanus and Neocalanus in high latitudes of the Northern Hemisphere. Hydrobiologia 167/168:127-142.
CONOVER, R.J., and CORNER, E.D.S. 1968. Respiration and nitrogen excretion by some marine zooplankton in relation to their life cycles. Journal of the Marine Biological Association of the United Kingdom 48:49-75.

CONOVER, R.J., and HUNTLEY, M. 1991. Copepods in ice-covered seas - Distribution, adaptations to seasonally limited food, metabolism, growth patterns and life cycle strategies in polar seas. Journal of Marine Systems 2:1-41.

CONOVER, R.J., HARRIS, L.R., and BEDO, A.W. 1991. Copepods in cold oligotrophic waters - How do they cope? Proceedings of the Fourth International Conference on Copepoda; Bulletin of the Plankton Society of Japan, Special Volume. 177-199.

CONOVER, R.J., HERMAN, A.W., PRINSENBERG, S.J., and HARRIS, L.R. 1986. Distribution of and feeding by the copepod Pseudocalanus under fast ice during the arctic spring. Science 232:1245-1247.

COTA, G.F., PRINSENBERG, S.J., BENNETT, E.B., LODER, J.W., LEWIS, M.R., ANNING, J.L., WATSON, N.H.F., and HARRIS, L.R. 1987. Nutrient fluxes during extended blooms of arctic ice algae. Journal of Geophysical Research 92(C2):1951-1962.

CROSS, W.E. 1982. Under-ice biota at the Pond Inlet ice edge and in adjacent fast ice areas during spring. Arctic 35(1):13-27.

DAWSON, J.K. 1978. Vertical distribution of Calanus hyperboreus in the central Arctic Ocean. Limnology and Oceanography 23(5):950-957.

ELGMORK, K. 1955. A resting stage without encystment in the annual cycle of the freshwater copepod Cyclops strenuus strenuus. Ecology 36:739-743.

EMERSON, E.W., and ROFF, J.C. 1987. Implications of fecal pellet size and zooplankton behaviour to estimates of pelagic-benthic carbon flux. Marine Ecology Progress Series 35:251-257.

GARRISON, D.L., CLOSE, A.R., and REIMNITZ, E. 1990. Microorganisms concentrated by frazil ice. Evidence from laboratory experiments and field measurements. In: Ackerley, S.F., and Weeks, W.F., eds. Sea ice properties and processes. U.S. Army Corps of Engineers (CRREL) Monograph 90-1:92-96.

GRAINGER, E.H. 1959. The annual oceanographic cycle at Igloolik in the Canadian Arctic. 1. The zooplankton and physical and chemical observations. Journal of the Fisheries Research Board of Canada 16(4):453-501.

GRAINGER, E.H., MOHAMMED, A.A., and LOVRITY, J.E. 1985. The sea-ice fauna of Frobisher Bay, arctic Canada. Arctic 38(1):23-30.

GRICE, G.D., and MARCUS, N.H. 1981. Dormant eggs of marine copepods. Oceanography and Marine Biology Annual Review. 19:125-140.

HAGEN, W. 1988. Zur Bedeutung der Lipide im antarktischen Zooplankton. Berichte zur Polarforschungen 49:1-129.

HARRIS, L.R. 1992. The importance of ice algae as an early season food source for arctic pelagic copepods. M.Sc. thesis, Dalhousie University. $96 \mathrm{p}$.

HARRISON, W.G., COTA, G.F., and SMITH, R.E.H. 1990. Nitrogen uilization in ice algal communities of Barrow Strait, Northwest Territories, Canada. Marine Ecology Progress Series 67:275-283.

HEAD, E.J.H., and CONOVER, R.J. 1983. Induction of digestive enzymes in Calanus hyperboreus. Marine Biology Letters 4:219-231.

HEAD, E.J.H., and HARRIS, L.R. 1985. Physiological and biochemical changes in Calanus hyperboreus from Jones Sound, N.W.T. during the transition from summer feeding to overwintering condition. Polar Biology 4:99-106.

HOPKINS, C.C.E. 1981. Ecological investigations on the zooplankton of Balsfjorden, northern Norway: Changes in zooplankton abundance and biomass in relation to phytoplankton and hydrography, March 1976 - February 1977. Kieler Meeresforschungen, Sonderheit 5:124-139.

KERN, J.C., and CAREY, A.G., Jr. 1983. The faunal assemblage inhabiting seasonal sea ice in the nearshore Arctic Ocean with emphasis on copepods. Marine Ecology Progress Series 10(2):159-167.

KILS, U. 1981. Swimming behavior, swimming performance and energy balance of Antarctic krill Euphausia superba. Biomass Science Series 3:1-233.

LEE, R.F. 1974. Lipid composition of the copepod Calanus hyperboreus from the Arctic Ocean. Changes with depth and season. Marine Biology 26:313-318.

LEWIS, P.N.B. 1987. Energetics of the arctic sub-ice amphipod Weyprechtia pinguis. M.Sc. thesis, Department of Zoology, University of Manitoba. $98 \mathrm{p}$.

MACLELLAN, D.C. 1967. The annual cycle of certain calanoid species in West Greenland. Canadian Journal of Zoology 45:101-115. 
MARCUS, N.H. 1990. Calanoid copepod, cladoceran, and rotifer eggs in sea-bottom sediments of northern California coastal water: Identification, occurrence and hatching. Marine Biology 105:413-418. ØSTVEDT, O.-J. 1955. Zooplankton investigations from Weathership M in the Norwegian Sea, 1948-1949. Hvalrådets Skrifter 1955(40):1-93.

PRINSENBERG, S.J., and BENNETT, E.B. 1987. Mixing and transports in Barrow Strait, the central part of the Northwest Passage. Continental Shelf Research 7(8):913-935.

PRINSENBERG, S.J., and BENNETT, E.B. 1989. Vertical variations of tidal currents in shallow land fast ice-covered regions. Journal of Physical Oceanography 19(9):1268-1278.

RUDYAKOV, Yu.A. 1983. Vertical distribution of Calanus hyperboreus (Copepoda) in the central Arctic Basin. Oceanology 23(2):249-254.

RUNGE, J.A., and INGRAM, R.G. 1988. Underice grazing by planktonic, calanoid copepods in relation to a bloom of ice microalgae in southeastern Hudson Bay. Limnology and Oceanography 33(2):280-286.

SARGENT, J.R., GATTEN, R.R., and HENDERSON, R.J. 1981. Lipid biochemistry of zooplankton from high latitudes. Oceanis 7(6):623-632.

SMITH, S.L., and SCHNACK-SCHIEL, S.B. 1990. Polar zooplankton. In: Smith, W.O., Jr., ed. Polar oceanography, Part B. Chemistry, biology and geology. New York: Academic Press. 527-598.
SMITH, R.E.H., HARRISON, W.G., HARRIS, L.R., and HERMAN, A.W. 1990. Vertical fine structure of particulate matter and nutrients in sea ice of the High Arctic. Canadian Journal of Fisheries and Aquatic Science 47:1348-1355.

STRETCH, J.J., HAMNER, P.P., HAMNER, W.M., MICHEL, W.C., COOK, J., and SULLIVAN, C.W. 1988. Foraging behavior of Antarctic krill on sea ice microalgae. Marine Ecology Progress Series 44:131-139.

TANDE, K.S., HASSEL, A., and SLAGSTAD, D. 1985. Gonad maturation and possible life cycle strategies in Calanus finmarchicus and Calanus glacialis in the northwestern part of the Barents Sea. In: Gray, J.S., and Christiansen, M.E., eds. Marine biology of polar regions and effects of stress on marine organisms. New York: John Wiley and Sons. 141-155.

USSING, H. 1938. The biology of some important plankton animals in the fjords of East Greenland. Meddelelser om Grønland 100(7):1-108.

WELCH, H. 1991. Comparisons between lakes and seas during the arctic winter. Arctic and Alpine Research 23:11-23.

WELCH, H.E., and BERGMANN, M.A. 1989. The seasonal development of ice algae and its prediction from environmental factors near Resolute, N.W.T., Canada. Canadian Journal of Fisheries and Aquatic Sciences 46:1793-1804. 